\title{
Editorial
}

\section{Agon: A Short History of Contest in Sport}

Authors' contribution:

A) conception and design of the study

B) acquisition of data

C) analysis and interpretation of data

D) manuscript preparation

E) obtaining funding

\section{Ejgil Jespersen}

Józef Pitsudski University of Physical Education in Warsaw, Department of Health Science in Biala Podlaska, Poland

\section{Introduction}

Sometime ago Olav Ballisager and I were sharing memories about our involvement in institutionalizing a field of sport studies and research in the 80's in Denmark. One event turned out to be a very remarkable and promising one. It took place in July in 1980 at Gerlev folk high school of sport. More than 200 persons were gathered to rediscover their bodies in modern dance together with outstanding American instructors like Judith Chaffe, Adrienne Hawkins and Betty Toman. Occasionally, there were also opportunities for learning about body and movement in cultural, philosophical and educational perspectives with excellent American researchers like John W. Loy, Susan Birrell, the English-born Alan G. Ingham, Seymour Kleinman and the Australian-born John Cheffers.

All that was put together by Olav Ballisager, a Danish gym teacher with creative ideas of challenging traditional ways of doing gymnastics and sports. The Institute of Scandinavian Physical Culture (ISPC) was inaugurated at this memorable event in Gerlev, and the ISPC existed as a private operator in about 25 years with exchange programs for scholars and students from many parts of the world. In 1997 the ISPC was somehow revived as part of a new program of sport studies at Aarhus University located in Aarhus, Denmark.

When we were talking about people involved throughout all these years, one person caught our attention especially, namely John W. Loy who are among the pioneers in establishing the field of sport sociology back in the 60s and 70s. ${ }^{1}$ We had learned about his efforts through "Sport, Culture, and Society" from 1969, a reader on the sociology of sport edited with Gerald S. Kenyon. (Loy \& Kenyon, 1969). Loy wrote, among other things, about the nature of sport and Kenyon about a conceptual model for characterizing physical activity. Their knowledge and viewpoints were albeit American also relevant for the rising debate on sport and society in Denmark in the 70s characterized by conflicts between an elite-oriented sport movement and a popular or massoriented movement of gymnastics and sports in a broader sense, between "lex sportiva" and politization of sport.

\footnotetext{
${ }^{1}$ On the 50th anniversary of the International Sociology of Sport (ISSA) and International Review for the Sociology of Sport (IRSS), whose founding editor-in-chief was Andrzej Wohl, key foundational scholar in the sociology of sport John W. Loy (2015) assesses the development of the field by focusing on larger questions of theory and methodological tactics.
} 


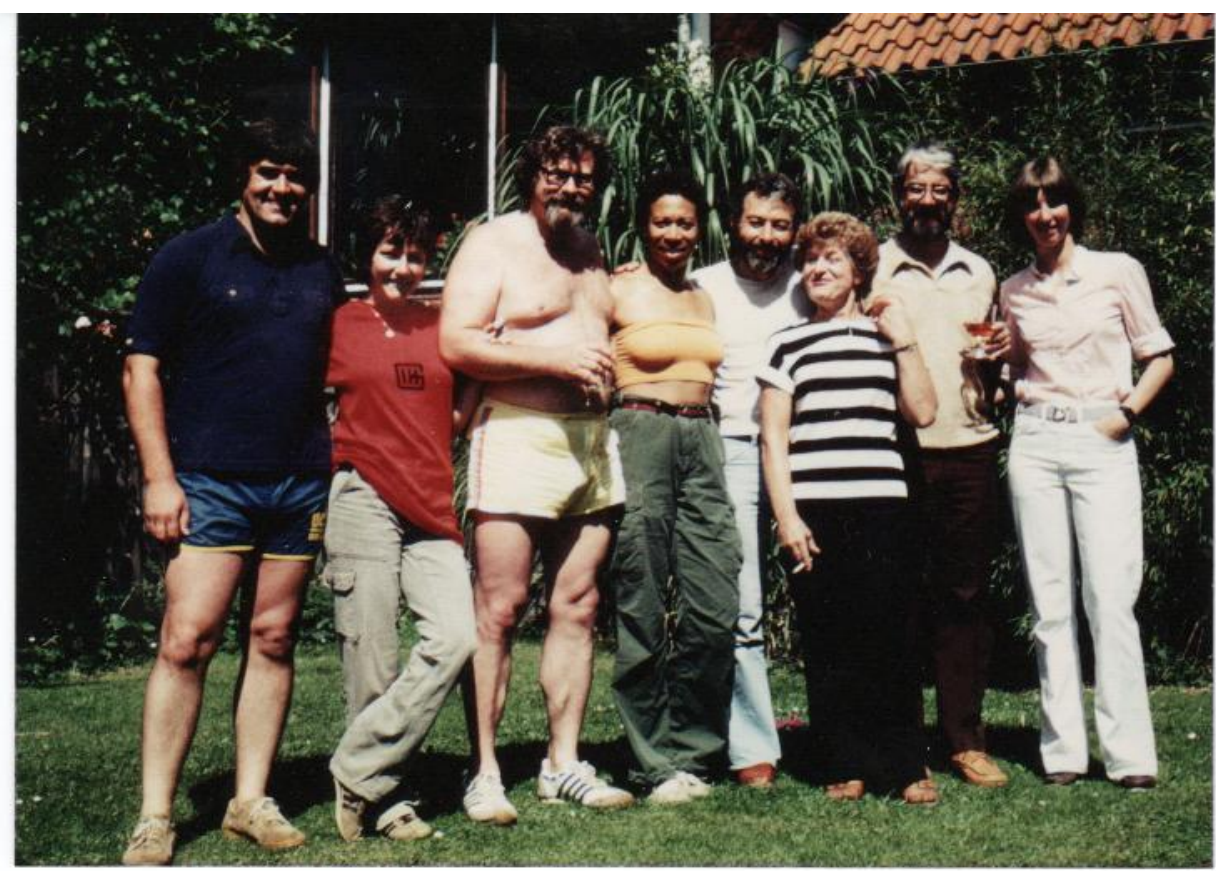

Photo 1. At Gerlev folk high school of sport, July 1980

From the left: Alan G. Ingham, Judith Chaffe, John Cheffers, Adriene Hawkins, Seymour Kleinman, Betty Toman, John W. Loy and Susan Birrell

Source: archive of the author.

In 1984 Olav Ballisager edited a book on "Sport and Agon" dealing with the environments as well as the inner life of sports (Ballisager, 1984). Loy was among the contributors. However, the book did not receive any great attention compared to, for example, a book on the history of gymnastics and sports entitled "The Struggle for the Body" written by Ove Korsgaard (1982), the principal of Gerlev folk high school of sport. It was apparently not possible to be a critical and curly mind and, at the same time, show some understanding of agonistic efforts in the world of sport.

Korsgaard (1986; 2018) developed subsequently a "Grundtvigian" concept of struggle named "circular motion" as a Nordic variant of agon ${ }^{2}$, whilst Claus Bøje (2002), a cultural politician, launched an educational variant of struggle, which side by side with play, dance and contemplation became a renewed mission for Gerlev folk high school of sport.

Thus, I asked Ballisager: What do you think about agon today?

Without answering directly, he referred to an unpublished paper by John W. Loy with W. Robert Morford as co-author on "The Agon Motif: Redux. A Study of the Contest Element in Sport". After having read it I thought it deserved a publication, although it was presented as a conference paper back in 2009, and the co-author Robert Morford in the meantime was deceased.

The publication of this excellent paper is now realized in a special issue of Physical Culture and Sport. Studies and Research on "The Agon Motif" including also an introduction by Roland Renson, and commentaries by Olav Ballisager, R. Scott Kretchmar and myself as well as a perspectival article on physical culture by Jerzy Kosiewicz.

\footnotetext{
${ }^{2}$ The German philosopher Johann Gottfried Herder (1744 - 1803) was also interested in circular motion (German "Kreisbewegung").
} 
The Agon Motif-paper was presented at a symposium on 12 June 2009 on "Homo Movens: International symposium on movement culture" at the occasion of Roland Renson's "rite of passage" to the emeritus status at the KU Leuven. In his introduction, Renson is trying to clarify the concepts of "movement culture" and "ludodiversity", which he often had the chance to discuss with John Loy personally. Renson consider sport as an anachronistic and ethnocentric term, both from a diachronic and from a cross-cultural perspective. Therefore, we should, rather, look at sport in a broader perspective of movement culture embracing not only contests, but exercise, performance, acrobatics/dance, play and games. Renson is particularly a spokesman for play and games and has coined a term of "ludodiversity" in order to raise our awareness for safeguarding this cultural heritage of "endangered movement species".

In the keynote on "The Agon Motif: Redux" John W. Loy and Robert Morford is arguing, that the contest element of modern sport has its ancient roots in the "agon" of early Greek life. They begin with an overview of the material and historical continuities in the social development of sport, followed by a discussion of their suppositions regarding the original linkage of sport and war in terms of what they call the agon motif, and conclude with speculations about residuals of the agon motif in modern sport. They argue it is important to recognize that notwithstanding of the many transitions and transformations in the social development of sport since the agon of Homeric and Hellenic Greek cultures there are notable, long-standing, material and historical continuities in the structure of sport and the ethos of agonal contests.

Loy and Morford emphasizes a close link to the cult of masculinity and masculine domination in the Western world, since the primary avenues of pursuing the agon motif through war and sport are two of the most highly and rigidly "gendered" activities in the history of humankind. They suggest that the most fundamental dynamic of the agon motif as well as the most enduring residual of the agon motif in modern sport is the pursuit of prestige, honor and excellence through physical prowess. The ethical framework of archaic (heroic) agon represents the epitome of a morality of honor and an ethics of virtue and offers a largely unfamiliar picture from a contemporary viewpoint of winning and losing in sport.

Olav Ballisager offers in his commentary to the agon motif some old Nordic examples on games - possibly with an agonal element. Then he is focusing on moral and character in order to identify some sort or a vestige of agon and revisit physical culture in terms of "idrcet", an old Nordic word for athletics and sport. Finally, he asks if there is - atavistic or not - in the modern world any glimpse of agonal behavior to be found and appreciated within the three realms or categories, which could be pillars of a physical education program: Nature, combat/competition and aesthetics.

R. Scott Kretchmar attempts in his commentary to do two things-first, he identifies implications of some conceptual distinctions, and second, he points out normative questions raised by the Loy/Morford analysis. Kretchmar finds it worthwhile to differentiate clearly between tests and contests. If the historical and sociocultural spotlight were turned on sporting "tests" rather than "contests", that is, on trying to solve physically demanding problems well rather than trying to solve them better than at least one other party, then another story than the agonal account could be told. War would probably no longer serve as the best historical and prehistorical analogue for sport. Rather, it might be hunting. Then, Kretchmar adds, that, on one hand, modern competitive sport is far less violent and, therefore, far more defensible today than it was previously. On the other hand, joy in playing is often sacrificed on the altar of any number of extrinsic rewards. Success, even gained by questionable means, replaces skill-based and virtue-generated achievement. This threatens the connection endorsed by MacIntyre between practices and virtues.

Finally, I am in my commentary asking: How is it possible to somehow maintain a vestige of ancient agon in terms of the pursuit of honor, whilst dignity has replaced honor as the ground on which an individual's legal status rests in modernity? I take the German social-philosopher Axel Honneth (1995) as a prime example of spelling out the replacement of honor with dignity in what he names "the struggle for recognition". However, in a historical perspective it looks like, that dignity can be understood as a distribution of honor rather than as 
an oppositional concept of honor. Recognition should not only be conceptualized at the categorical level, but also understood in terms of "comparative recognition", which sorts members of a group into an intra-group hierarchy based on their relative merits and, thereby, pave the way for self-esteem.

Furthermore, Honneth (2008) develops his concept of recognition to a two-level one by including a primordial recognition in terms of a fundamental practical engagement with the world, prior to the subject-object dichotomy, and based upon his former concept of basic self-confidence in terms of love and friendship. This approach opens for grounding honor in the mimetic faculty at the inter-corporeal level, which has been rather neglected in policy and social research because of its non-epistemic and pre-reflective existential significance across conflictual interests. It is a kind of elementary responsiveness, which always and necessarily contains an element of involuntary openness or devotedness in the bodily-affective sphere. Therefore, I suggest taking mimesis into account besides considering honor and dignity in modern sport.

As Renson stresses in his introduction, sport is only a part of what he names "movement culture". Others like Henning Eichberg (2009) have focused on "body culture" (German "Körperkultur") or like Alan G. Ingham (1997) on "physical culture" as a general concept for institutionalized forms of movement ${ }^{3}$. The main contested viewpoint is how to deal with and conceptualize the human body in movement in practice and theory. From an objective point of view bodies are just objects in motion, which are measurable in terms of results in sports and sport sciences or, in a broader sense, kinesiology. However, from a participant point of view, bodies are (also) felt and subjects of movement and perception. Modern dance is a prime example of how to cultivate the body in this concrete instance. Therefore, we need to address modern sport and dance in a wider cultural perspective, as Jerzy Kosiewicz argues in his article on "Championing Physical Cultural Sciences" 4.

"Physical culture" is the general concept for what is going on at the Polish universities of physical education and, therefore, it is important to notice the meaning of the term "physical culture" associated primarily (referring to the etymology of the word "culture") with "colo, -ere" of the human body - that is, with cultivating and taking care of human "physis" - obviously in the context of social and natural environment, as Kosiewicz is proclaiming. If or when the social and biological sciences struggle with each other for hegemony, then a historical perspective is much needed in order to understand the underpinnings for this struggle in a world embracing a host of different physical cultural practices and a gentle selection of relevant scientific disciplines or "principalities".

Thus, Kosiewicz shares his thorough insight in the history and theory of science related to physical culture and points out, that the Russian term "fizkultura", which was introduced after the 1917 October Revolution as a socialist propaganda concept, is in fact not a forerunner in the field. It was earlier introduced by the Polish statesman Jozef Pilsudski in 1914, who according to Kosiewicz became acquainted with the term "physical culture" in London, where at the end of the $19^{\text {th }}$ and beginning of the $20^{\text {th }}$ century a magazine entitled "Physical Culture" was accessible. It was published since 1899 in USA by Bernard MacFadden, who was a body-builder by vocation, an expert in principles of healthy nutrition and a proponent of natural methods of healing. The first issue of the "MacFadden's Encyclopedia of Physical Culture" with a naturalist, biological and medical character was published as early as in 1911 and contributed heavily to the popularization of the term "physical culture" in USA and other English-speaking countries.

\footnotetext{
${ }^{3}$ Ingham (1997) offers the following, value-referenced, focus statement for the Department of Physical Culture Studies (DPCS): "The DPCS consists of cross- and inter-disciplinary studies of practices in physical culture (e.g. movement activities, exercise, nutrition, training, enculturation, recreational and representational sport) which critically assess and promote programs that focus upon the intersections of physical activities, health behaviors, and movement-related lifestyle choices", p. 165.

${ }^{4}$ The article is a revised version of J. Kosiewicz (2010). Social and Biological Context of Physical Culture and Sport. Physical Culture and Sport. Studies and Research L, pp. 5-31.
} 
In philosophy, naturalism is the idea or belief that only natural laws and forces operate in the world. That is, if this viewpoint is (becoming) supreme in physical culture and education, then there is no longer room for neither active human subjects nor the cultivation of the human body, nor a role for the social sciences and humanities. We will stay back without any human open-mindedness and inclination to make sense of physical culture, because, as Kosiewicz underlines, what matters in cultural reflection (in the field of physical culture) concerning, for example, sports activity is not movement as such - as a purely physical phenomenon - but only such a form of movement which has been attributed with conventionalized social values of symbolic and autotelic character.

\section{Acknowledgements}

Many thanks to John W. Loy, Roland Renson, Olav Ballisager and R. Scott Kretchmar for sharing their knowledge and viewpoints of a key trait in the world of sport history: "The Agon Motif" and to the founding editor-in-chief of Physical Culture and Sport. Studies and Research Jerzy Kosiewicz for welcoming this special issue and for contributing with an article on "Championing Physical Cultural Sciences."

\section{REFERENCES}

Ballisager, O. (1984). Idrcet og Agon. Tekster om Idrcettens ydre og indre miljø /Sport and Agon. Texts on the Outer and Inner Environment of Sport. Hørning: Agon Publ.

Bøje, C. (2002). Idrættens kvaliteter /Qualities of Sport/. KvaN: et tidsskrift for laereruddannelsen og folkeskolen, 62, 7 16.

Eichberg, H. (2009). Body Culture. Physical Culture and Sport. Studies and Research, XLVI, pp. 79-98.

Ingham, A.G. (1997). Toward a Department of Physical Culture Studies and an End to Tribal Warfare. In J.-M. FernandezBalboa (Ed.), Critical Postmodernism in Human Movement, Physical Education and Sport (pp. 157-180). New York, NY: State University University of New York Press.

Korsgaard, O. (1982). Kampen om kroppen. Dansk idrcets historie gennem 200 år /The Struggle for the Body. Danish Sport History Over 200 Years/. København: Gyldendal.

Korsgaard, O. (1986). Kredsgang. Grundtvig som bokser / Circular Motion. Grundtvig as Boxer/. København: Gyldendal. Korsgaard, O. (2018). Grundtvig rundt. En guide /Around Grundtvig. A guidel. København: Gyldendal, pp. 211-227.

Kosiewicz, J. (2010). Social and Biological Context of Physical Culture and Sport. Physical Culture and Sport. Studies and Research, L, 5-31.

Loy, J.W. (2015). Assessing the Sociology of Sport: On Theory and Method. International Review for the Sociology of Sport 50(4-5), 512-518.

Loy, J.W. \& Kenyon, G.S. (1969). Sport, Culture, and Society. A Reader on the Sociology of Sport. New York: The Macmillan Company.

\section{AUTHOR'S ADDRESS:}

Ejgil Jespersen

Józef Piłsudski University of Physical Education in Warsaw, branch in Biała Podlaska

Akademicka 2

21-500 Biała Podlaska

Poland

Email: e.jespersen@awf-bp.edu.pl

Received: 10 November 2018; Accepted: 11 February 2019 